\title{
Ruegeria mobilis sp. nov., a member of the Alphaproteobacteria isolated in Japan and Palau
}

Correspondence

Yuki Muramatsu

muramatsu-yuki@nite.go.jp

\author{
Yuki Muramatsu, ${ }^{1}$ Yoshihito Uchino, ${ }^{1}$ Hiroaki Kasai, ${ }^{2}$ Ken-ichiro Suzuki ${ }^{1}$ \\ and Yasuyoshi Nakagawa ${ }^{1}$
}

\author{
${ }^{1}$ Biological Resource Center (NBRC), Department of Biotechnology, National Institute of \\ Technology and Evaluation, Kisarazu, Chiba 292-0818, Japan \\ ${ }^{2}$ Marine Biotechnology Institute Co., Ltd, Kamaishi, Iwate 026-0001, Japan
}

The taxonomic positions of two bacterial strains, MBIC01146 ${ }^{\top}$ and MBIC01099, isolated from marine environments of Japan and Palau, respectively, were determined by using a polyphasic approach. The bacteria were aerobic, motile, Gram-negative rods and formed star-shaped aggregations. The $\mathrm{G}+\mathrm{C}$ content of the genomic DNA ranged from 58.5 to $58.7 \mathrm{~mol} \%$. The major respiratory quinone was ubiquinone-10 and the predominant cellular fatty acids were $C_{16: 0}$, $\mathrm{C}_{18: 1} \omega 6 c$ and $\mathrm{C}_{18: 1} \omega 7 c$. 16S rRNA gene sequence analyses based on both neighbour-joining and maximum-parsimony methods revealed that strains $\mathrm{MBIC} 01146^{\top}$ and $\mathrm{MBIC01099}$ were positioned within the cluster comprising Ruegeria atlantica and Silicibacter lacuscaerulensis within subgroup $\alpha-3$ of the Proteobacteria. The phenotypic and chemotaxonomic characteristics of the novel strains were similar to those of Ruegeria atlantica; however, DNA-DNA hybridization tests showed that the isolates represented an independent species. The isolates could be differentiated from Ruegeria atlantica based on several characteristics. Therefore, strains MBIC01146 ${ }^{\top}$ and $\mathrm{MBIC} 01099$ are considered to represent a novel species of the genus Ruegeria, for which the name Ruegeria mobilis sp. nov. is proposed. The type strain is $\mathrm{MBIC} 1146^{\top}\left(=\mathrm{NBRC} 101030^{\top}=\mathrm{CIP}\right.$ $109181^{\top}$ ). An emended description of Ruegeria atlantica Uchino et al. 1999 is also given.
Strain MBIC01146 ${ }^{\mathrm{T}}$ was isolated from a slime attached to a glass slide that was floated on the sea surface for 1 day at Ishigaki island, Japan, in 1990. The slime was diluted with sterilized seawater and then cultured on a B2 agar plate (Izumida et al., 1995). Strain MBIC01099 was isolated from a coelenterate (Hexacorallia sp.) recovered from Honeybee Channel, Palau, in 1991. The coelenterate was homogenized and diluted with sterilized seawater and then enriched in B6 medium [0.25 g Polypepton, $0.25 \mathrm{~g}$ Polypepton S, $0.25 \mathrm{~g}$ Polypepton Y (all Nihon Pharmaceuticals), 0.5 g brain heart infusion (Difco), $1.0 \mathrm{~g}$ yeast extract, $0.25 \mathrm{~g}$ malt extract, $0.25 \mathrm{~g}$ soluble starch, $0.5 \mathrm{~g}$ potato glucose broth (Difco), $26.0 \mathrm{~g}$ sea salt (Tropic Marin) and $0.5 \mathrm{~g}$ HEPES buffer, per litre distilled water, $\mathrm{pH}$ 7.7] supplemented with $10 \mathrm{mM}$ eosin Y (Wako Pure Chemical Industries). The enriched sample was incubated at $25^{\circ} \mathrm{C}$ for 1 day on a B6 agar

The GenBank/EMBL/DDBJ accession numbers for the 16S rRNA gene sequences of Ruegeria mobilis MBIC01146 ${ }^{\top}$ and MBIC01099, Ruegeria atlantica NBRC $15792^{\top}$, Thalassobius gelatinovorus NBRC $15761^{\top}$ and Marinovum algicola NBRC 16653 ${ }^{\top}$ are AB255401, AB255400, AB255399, AB289591 and AB289592, respectively.

A maximum-parsimony tree showing the phylogenetic positions of strains MBIC01146 ${ }^{\top}$ and MBIC01099 based on 16S rRNA gene sequences is available as supplementary material with the online version of this paper. medium. Based on initial 16S rRNA gene sequence analysis, the isolates were tentatively identified as representing marine Agrobacterium species belonging to subgroup $\alpha-3$ of the Proteobacteria, given that their phylogenetically closest relative was Agrobacterium atlanticum. A. atlanticum was reclassified within the genus Ruegeria as three species, Ruegeria atlantica (type species), Ruegeria gelatinovorans and Ruegeria algicola (Uchino et al., 1998). Recently, the latter two species were reclassified as Thalassobius gelatinovorus and Marinovum algicola, respectively (Arahal et al., 2005; Martens et al., 2006). As a result, the genus Ruegeria now comprises a single recognized species. In addition, several new genera have been proposed within subgroup $\alpha-3$ of the Proteobacteria (e.g. Labrenz et al., 1999; Schaefer et al., 2002). Here we characterized two strains, MBIC01146 ${ }^{\mathrm{T}}$ and MBIC01099, based on genomic, chemotaxonomic and phenotypic data.

Cellular morphology was observed under light and transmission electron microscopy. For the latter, fresh bacterial cultures were negatively stained with $1 \%$ phosphotungstic acid ( $\mathrm{pH}$ 7.0) and observed under a Hitachi $\mathrm{H}$ 7600 transmission electron microscope at an accelerating voltage of $80 \mathrm{kV}$. Cells of strains MBIC01146 ${ }^{\mathrm{T}}$ and MBIC01099 formed star-shaped aggregates, similar to those of $R$. atlantica NBRC $15792^{\mathrm{T}}$ (Rüger \& Höfle, 

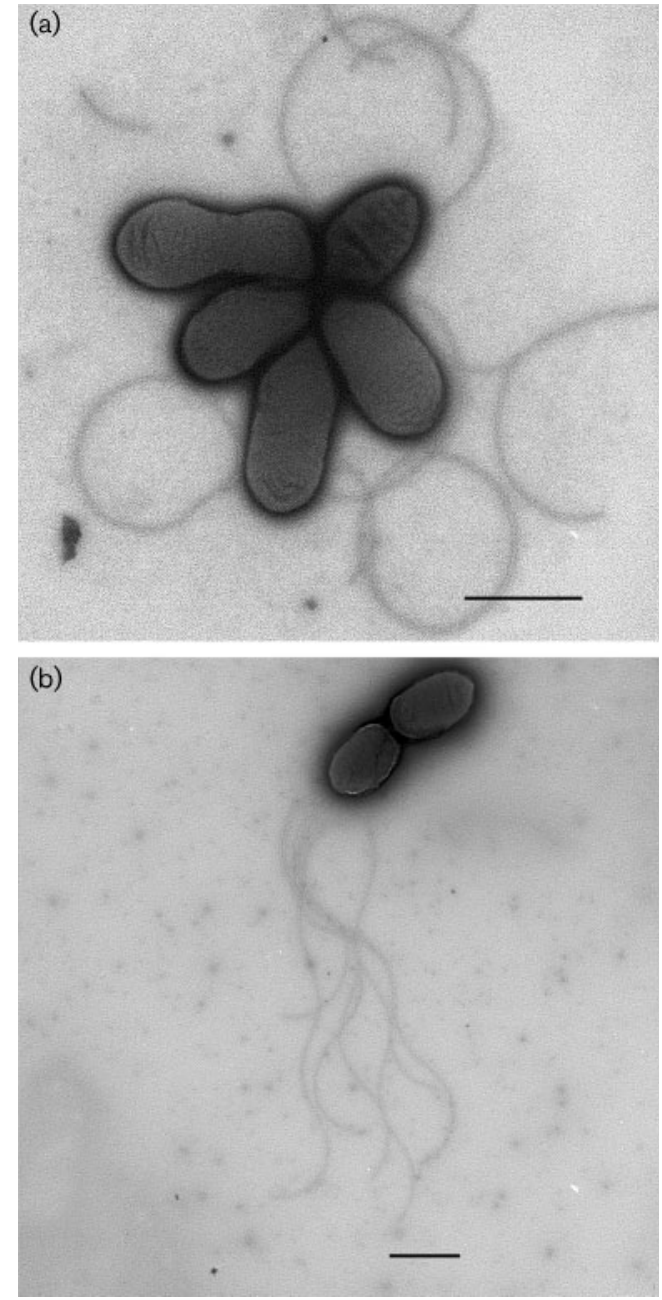

Fig. 1. Transmission electron micrographs of negatively stained cells of strain MBIC01146 ${ }^{\top}$. (a) Star-shaped aggregate formation; (b) cell showing several polar flagella. Bars, $1 \mu \mathrm{m}$.

1992), when they were statically cultivated to late exponential phase for $20 \mathrm{~h}$ in one-fifth-strength LBM medium (Suzuki et al., 2001) (Fig. 1a). Bruhn et al. (2005) reported that Roseobactersp. 27-4 formed star-shaped aggregates with pigment production. The two new isolates formed starshaped aggregates without colour changes. Cells were motile and possessed several polar flagella (Fig. 1b). In contrast, we confirmed that cells of $R$. atlantica NBRC $15792^{\mathrm{T}}$ were non-motile, as previously reported (Rüger \& Höfle, 1992; Uchino et al., 1998).

Genomic DNA extraction and 16S rRNA gene sequencing were performed as described by Nakagawa et al. (2002). Sequence data obtained were aligned with those of representative members of subgroup $\alpha-3$ of the Proteobacteria by using CLUSTAL X (Thompson et al., 1997) and then modified manually by referring to the $16 \mathrm{~S}$ rRNA gene secondary structure of Escherichia coli (Gutell et al., 1994) and using the Se-Al v2.0 alignment editor (A. Rambaut; available at http:// evolve.zoo.ox.ac.uk/). Phylogenetic trees were constructed by the neighbour-joining method (Saitou \& Nei, 1987) with calculated $K_{\text {nuc }}$ values (Kimura, 1980), as well as the maximum-parsimony method with PAUP $4.0 \mathrm{~b} 10$ (Swofford, 2002). Topology of the trees was evaluated by the bootstrap analysis method of Felsenstein (1985) with 1000 replicates. Almost complete sequences of the 16S rRNA genes from positions 28-1494 according to the E. coli numbering system (Brosius et al., 1978) were determined for strains MBIC01146 ${ }^{\mathrm{T}}$ and MBIC01099 as well as for $R$. atlantica NBRC $15792^{\mathrm{T}}$. Analysis of the $16 \mathrm{~S}$ rRNA gene sequences of the unclassified strains resulted in their clustering with $R$. atlantica, Silicibacter lacuscaerulensis and Silicibacter pomeroyi within subgroup $\alpha-3$ of the Proteobacteria (Fig. 2 and Supplementary Fig. S1 in IJSEM Online). Levels of similarity in the 16S rRNA gene sequences between strain MBIC01146 ${ }^{\mathrm{T}}$ and $R$. atlantica NBRC $15792^{\mathrm{T}}$, S. lacuscaerulensis ITI- $1157^{\mathrm{T}}$ and S. pomeroyi DSS- ${ }^{\mathrm{T}}$ were $97.1,96.6$ and $96.3 \%$, respectively.

DNA-DNA hybridization experiments were carried out in microplate wells by using photobiotin-labelled probes as described by Ezaki et al. (1989). The hybridization temperature was $48^{\circ} \mathrm{C}$ in $2 \times$ SSC containing $50 \%$ formamide.

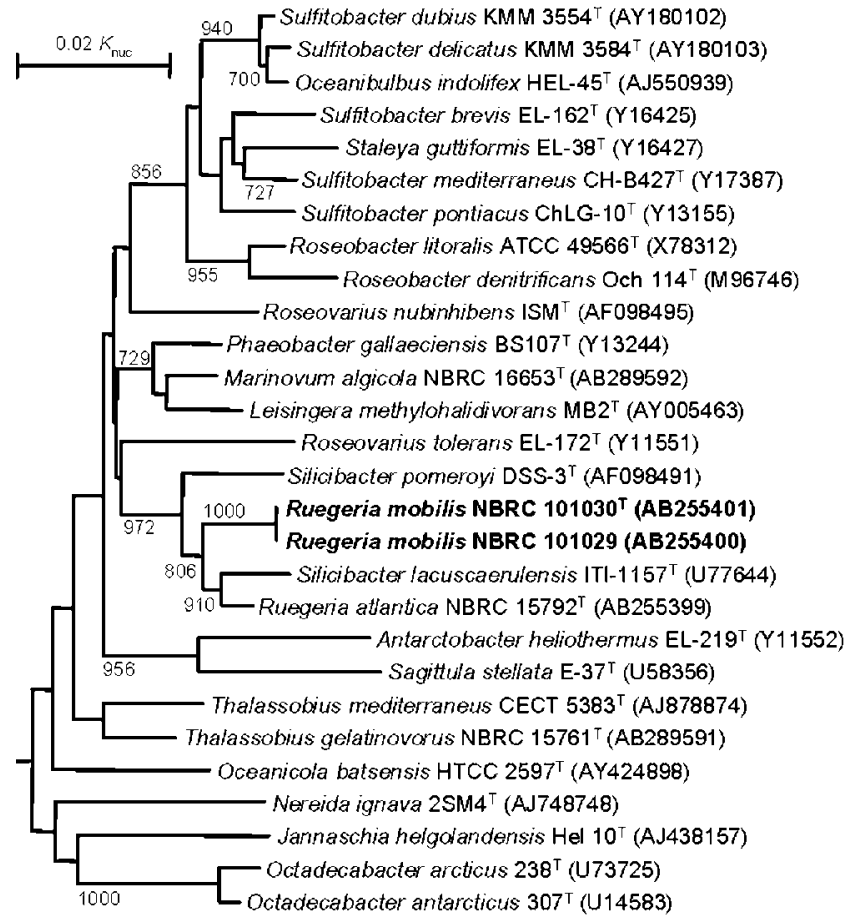

Fig. 2. Neighbour-joining tree showing the phylogenetic positions of strains MBIC01146 ${ }^{\top} \quad\left(=\mathrm{NBRC} 101030^{\top}\right)$ and MBIC01099 (=NBRC 101029) based on 16S rRNA gene sequences. Escherichia coli K-12 (GenBank accession no. E05133) was used as an outgroup (not shown). Bootstrap values of 700 or more in 1000 replicates are shown. Bar, 0.02 $K_{\text {nuc }}$ A maximum-parsimony tree is available as Supplementary Fig. S1 in IJSEM Online. 
The results indicated that strains $\mathrm{MBIC} 01146^{\mathrm{T}}$ and MBIC01099 represented a single species, given that their DNA-DNA relatedness values were above $75 \%$ (Wayne et al., 1987). Strain MBIC01146 ${ }^{\mathrm{T}}$ showed $4-5 \%$ DNA-DNA relatedness with $R$. atlantica NBRC $15792^{\mathrm{T}}$. Hybridizations between the new isolates and S. lacuscaerulensis ITI- $1157^{\mathrm{T}}$ were not performed because 16S rRNA gene sequence similarities between these taxa were below $96.6 \%$. It has been reported that if $16 \mathrm{~S}$ rRNA sequence similarities between two organisms are lower than $97 \%$, they must be classified as separate species (Wayne et al., 1987). G+C contents of the DNA samples were subsequently determined according to Mesbah et al. (1989). The values for strains MBIC01146 $^{\mathrm{T}}$ and MBIC01099 were 58.5 and $58.7 \mathrm{~mol} \%$, respectively, similar to the value of $59.4 \mathrm{~mol} \%$ obtained in this study for R. atlantica NBRC $15792^{\mathrm{T}}$. Reported DNA $\mathrm{G}+\mathrm{C}$ content values for the genus Silicibacter are 64.1$66.2 \mathrm{~mol} \%$ (Petursdottir \& Kristjansson, 1997; González et al., 2003; Whitman, 2006).

For analysis of whole-cell fatty acid composition, all strains were grown on Bacto marine agar 2216 (Difco) at $25^{\circ} \mathrm{C}$ for $48 \mathrm{~h}$. Fatty acid methyl esters were prepared and analysed according to the standard protocol described in the Microbial Identification System (Microbial ID). Strains MBIC01146 ${ }^{\mathrm{T}}$ and MBIC01099 showed similar fatty acid profiles, in which $\mathrm{C}_{16: 0}, \mathrm{C}_{18: 1} \omega 6 c$ and $\mathrm{C}_{18: 1} \omega 07 c$ were the dominant components (more than $5 \%$ of the total) (Table 1 ). The major fatty acids in $R$. atlantica NBRC $15792^{\mathrm{T}}$ were $\mathrm{C}_{16: 0}, \mathrm{C}_{18: 1} \omega 7 c$ and 11-methyl $\mathrm{C}_{18: 1} \omega 7 c$. The dominant fatty acids in S. lacuscaerulensis and $\mathrm{S}$. pomeroyi were reported to be $\mathrm{C}_{18: 0}, \mathrm{C}_{12: 0} 3-\mathrm{OH}$ and $\mathrm{C}_{18: 1} \omega 7 c$, and $\mathrm{C}_{16: 0}, \mathrm{C}_{12: 0} 3-\mathrm{OH}$ and $\mathrm{C}_{18: 1} \omega 7 c$, respectively (González et al., 2003). R. atlantica, S. lacuscaerulensis, S. pomeroyi and the new isolates had similar fatty acid contents in which the dominant component was $\mathrm{C}_{18: 1} \omega 7 \mathrm{c}$. Q-10 was found to be the major respiratory quinone in strains MBIC01146 and MBIC01099 as well as in R. atlantica, when extracted according to Nakagawa \& Yamasato (1993) and analysed by using an LC-MS $8000 \alpha$ spectrometer (Shimadzu).

Production of indole, $\mathrm{H}_{2} \mathrm{~S}$, oxidase and nitrate reductase was examined as described by Smibert \& Krieg (1981). Utilization of urea, sodium nitrate, ammonium sulfate, sodium glutamate, peptone (Difco) and Casamino acids as nitrogen sources was examined by using basal medium $(0.1 \%$ glucose, $0.02 \%$ sodium acetate, $70 \%$ artificial seawater, pH 7.2) supplemented with each element. Decomposition of urea was examined as described by Rustigian \& Stuart (1941). To analyse the growth response at different temperatures (increments of $\left.5^{\circ} \mathrm{C}\right)$ and $\mathrm{pH}$ values $(\mathrm{pH} 3-$ 11 , increments of $1 \mathrm{pH}$ unit), we used one-fifth-strength LBM medium for cultivation with shaking. $\mathrm{NaCl}$ range for growth was determined by using one-fifth-strength LB medium supplemented with $0,1,3,5,7$ or $10 \% \mathrm{NaCl}$. Carbohydrate assimilation was determined by using the API $50 \mathrm{CH}$ system (bioMérieux). Several colonies on agar plates were suspended in artificial seawater supplemented with
Table 1. Cellular fatty acid compositions (\%) of strains $\mathrm{MBIC} 01146^{\top}$ and MBIC01099 and members of the genera Ruegeria and Silicibacter

Strains: 1, MBIC01146 ${ }^{\mathrm{T}}$; 2, MBIC01099; 3, R. atlantica NBRC $15792^{\mathrm{T}}$; 4, S. lacuscaerulensis ITI- $1157^{\mathrm{T}}$ (data from González et al., 2003); 5, S. pomeroyi DSS-3 ${ }^{\mathrm{T}}$ (González et al., 2003). -, Not detected/not reported.

\begin{tabular}{|lccccc|}
\hline Fatty acid & $\mathbf{1}$ & $\mathbf{2}$ & $\mathbf{3}$ & $\mathbf{4}$ & $\mathbf{5}$ \\
\hline Straight-chain & & & & & \\
$\mathrm{C}_{10: 0}$ & - & - & 2.1 & 2.5 & 3.1 \\
$\mathrm{C}_{12: 0}$ & - & 0.2 & 2.6 & 2.1 & 1.1 \\
$\mathrm{C}_{16: 0}$ & 10.3 & 10.8 & 6.9 & 1.6 & 7.8 \\
$\mathrm{C}_{17: 0}$ & 0.2 & 0.3 & - & 0.3 & - \\
$\mathrm{C}_{18: 0}$ & 1.0 & 1.1 & 1.0 & 2.6 & 1.6 \\
Unsaturated & & & & & \\
$\mathrm{C}_{18: 1} \omega 6 c$ & 6.4 & 6.5 & - & - & - \\
$\mathrm{C}_{18: 1} \omega 7 c$ & 74.9 & 74.0 & 71.2 & 81.7 & 76.3 \\
$11-$ Methyl $\mathrm{C}_{18: 1}{ }^{*}$ & - & - & - & 2.2 & 1.9 \\
$11-$ Methyl $\mathrm{C}_{18: 1} \omega 7 c$ & 1.9 & 1.2 & 7.1 & - & - \\
$\mathrm{C}_{20: 1} 1 \omega 7 c$ & - & - & 0.2 & - & - \\
Hydroxy & & & & & \\
$\mathrm{C}_{10: 0}$ 3-OH & 2.0 & 2.2 & 0.4 & 1.6 & 0.6 \\
$\mathrm{C}_{12: 0}$ 3-OH & 0.3 & 0.5 & 4.7 & 4.0 & 4.9 \\
$\mathrm{C}_{16: 0}$ 2-OH & 0.4 & 0.5 & 3.4 & - & 2.8 \\
Summed feature 3 $\dagger$ & 0.5 & 0.5 & 0.3 & 0.3 & - \\
Unknown & 2.2 & 2.2 & 0.1 & - & - \\
\hline
\end{tabular}

${ }^{\star}$ The site of the double bond was not assigned by González et al. (2003).

† Summed features represent groups of two or three fatty acids that could not be separated by GLC with the MIDI system. Summed feature 3 comprises iso- $\mathrm{C}_{15: 0} 2-\mathrm{OH}$ and/or $\mathrm{C}_{16: 1} \omega 7 \mathrm{c}$.

$0.05 \%$ yeast extract (Lau et al., 2005) and were added to test strips. Colour was compared with medium in which no cells were suspended. No specific signals or acid production were observed with the carbon sources used in the API 20E, API 20NE, API ZYM and Biolog systems. Strains MBIC01146 ${ }^{\mathrm{T}}$, MBIC01099 and R. atlantica NBRC $15792^{\mathrm{T}}$ were positive for utilization of glucose in the API $50 \mathrm{CH}$ system. In contrast, it was reported that utilization of glucose was negative for S. lacuscaerulensis ITI- $1157^{\mathrm{T}}$ (Petursdottir \& Kristjansson, 1997). Other phenotypic characteristics of strains MBIC01146 ${ }^{\mathrm{T}}$ and MBIC01099 are summarized in the species description below and in Table 2 .

In the phylogenetic analysis of the $16 \mathrm{~S}$ rRNA gene sequences, strains MBIC01146 ${ }^{\mathrm{T}}$ and MBIC01099 clustered with species belonging to the genera Ruegeria and Silicibacter. 16S rRNA gene sequence analysis suggested that the genera Ruegeria and Silicibacter were closely related and should be integrated into one genus. However, their differential phenotypic properties did not support this unification. The genus Ruegeria Uchino et al. 1999 (Validation List No. 68) has priority over Silicibacter Petursdottir and Kristjansson 1999 (Validation 
Table 2. Differential phenotypic characteristics between strains $M B I C 01146^{\top}$ and $M B I C 01099$ and closely related taxa

Taxa: 1, strain MBIC01146 ${ }^{\mathrm{T}}$; 2, strain MBIC01099; 3, R. atlantica NBRC 15792 ${ }^{\mathrm{T}}$; 4, S. lacuscaerulensis ITI-1157 ${ }^{\mathrm{T}}$ (data from Petursdottir \& Kristjansson, 1997); 5, S. pomeroyi DSS-3 ${ }^{\mathrm{T}}$ (González et al., 2003; Whitman, 2006). +, Positive; -, negative; W, weakly positive; (W), weakly positive after 2 weeks; ND, no data. Strains MBIC01146 ${ }^{\mathrm{T}}$ and MBIC01099 and R. atlantica NBRC $15792^{\mathrm{T}}$ are all negative for utilization of $\mathrm{i}$-erythritol, $\mathrm{D}$-arabinose, L-xylose, methyl $\beta$-D-xyloside, sorbose, dulcitol, methyl $\gamma$-D-mannoside, methyl $\gamma$-D-glucoside, amygdalin, salicin, lactose, melibiose, inulin, melezitose, raffinose, starch, glycogen, gentiobiose, D-turanose, D-lyxose, D-tagatose, L-fucose and 5-ketogluconate (API 50CH).

\begin{tabular}{|c|c|c|c|c|c|}
\hline Characteristic & 1 & 2 & 3 & 4 & 5 \\
\hline Cell size $(\mu \mathrm{m})($ diameter $\times$ length $)$ & $0.6 \times 2.0$ & $0.8 \times 1.0$ & $0.8 \times 4.0$ & $0.6-0.8 \times 9-18$ & ND \\
\hline Motility & + & + & - & - & + \\
\hline Vacuole (inclusion body) & - & - & - & + & + \\
\hline \multicolumn{6}{|l|}{ Growth conditions } \\
\hline $\mathrm{NaCl}$ range (\%) [optimum] & $0-10[1]$ & $0-10[3]$ & $3-10[3]$ & $1.5-7[3.5]$ & $1.5-5.8$ \\
\hline Hydrolysis of gelatin & - & + & - & ND & + \\
\hline Nitrate reduction to nitrite & - & $\mathrm{W}$ & + & + & - \\
\hline Nitrite reduction to gas & - & - & + & ND & - \\
\hline \multicolumn{6}{|l|}{ Utilization, as sole nitrogen source, of: } \\
\hline Adonitol & + & + & - & ND & ND \\
\hline Glucose & + & + & + & - & + \\
\hline Fructose & + & + & - & $\mathrm{ND}$ & - \\
\hline Rhamnose & - & + & - & $\mathrm{ND}$ & - \\
\hline Mannitol & + & + & (w) & $\mathrm{ND}$ & - \\
\hline Sorbitol & W & W & - & ND & ND \\
\hline Arbutin & - & - & + & $\mathrm{ND}$ & ND \\
\hline Xylitol & + & + & - & $\mathrm{ND}$ & ND \\
\hline D-Fucose & + & + & - & $\mathrm{ND}$ & ND \\
\hline D-Arabitol & + & + & - & $\mathrm{ND}$ & ND \\
\hline L-Arabitol & $\mathrm{W}$ & + & - & ND & ND \\
\hline
\end{tabular}

List No. 71). We conclude that strains MBIC01146 ${ }^{\mathrm{T}}$ and MBIC01099 should be included in the genus Ruegeria based on similar morphological features, fatty acid compositions and DNA G + C contents. However, DNA-DNA hybridization experiments indicated that they constituted an independent species that was clearly differentiated from $R$. atlantica based on motility, ability to grow without $\mathrm{NaCl}$ and other characteristics summarized in Table 2. Thus, strains MBIC01146 ${ }^{\mathrm{T}}$ and MBIC01099 are considered to represent a novel species of the genus Ruegeria, for which the name Ruegeria mobilis sp. nov. is proposed. We emend below the species description of Ruegeria atlantica, based on detailed phenotypic characteristics obtained in the present study.

\section{Description of Ruegeria mobilis sp. nov.}

Ruegeria mobilis (mo'bi.lis. L. adj. mobilis mobile).

Cells are Gram-negative, aerobic, motile rods that are 1.0$2.0 \mu \mathrm{m}$ long and $0.6-0.8 \mu \mathrm{m}$ wide. Growth is detected at $5-35^{\circ} \mathrm{C}$ with an optimum at $25-30{ }^{\circ} \mathrm{C}$. $\mathrm{pH}$ range for growth is 5-11 with an optimum at $\mathrm{pH} 7$. Growth occurs at $0-10 \%$ $\mathrm{NaCl}$ with an optimum at $1-3 \%$. Oxidase- and catalasepositive. Alginic acid, tyrosine and aesculin are degraded, but agar, casein, cellulose, chitin, inulin, carboxymethylcellulose, Tween 80, DNA and yeast cells are not. $\mathrm{H}_{2} \mathrm{~S}$ and indole are not produced. Starch is not hydrolysed. Nitrate is not reduced to gas. Ammonium sulfate and urea are used as sole nitrogen sources for growth. Positive for utilization of 
L-arabinose, adonitol, fructose, mannitol, xylitol, D-fucose and D-arabitol, weakly positive for sorbitol and L-arabitol and negative for arbutin and gluconate as sole carbon sources with the API $50 \mathrm{CH}$ system. Major fatty acids are $\mathrm{C}_{16: 0}, \mathrm{C}_{18: 1} \omega 6 c$ and $\mathrm{C}_{18: 1} \omega 7 c$. $\mathrm{C}_{18: 0}, 11$-methyl $\mathrm{C}_{18: 1} \omega 7 c$ and $\mathrm{C}_{10: 0} 3-\mathrm{OH}$ are present as minor components. Major ubiquinone is Q-10. DNA G $+\mathrm{C}$ content of the type strain is $58.5 \mathrm{~mol} \%$.

The type strain, MBIC01146 ${ }^{\mathrm{T}}\left(=\mathrm{NBRC} 101030^{\mathrm{T}}=\mathrm{CIP}\right.$ $\left.109181^{\mathrm{T}}\right)$, was isolated from a marine slime in Japan. Strain MBIC01099 (=NBRC 101029) is also included in the species.

\section{Emended description of Ruegeria atlantica (Rüger and Höfle 1992) Uchino et al. 1999}

The emended description here is based on data from Rüger \& Höfle (1992), Uchino et al. (1998), Martens et al. (2006) and this study. Cells are Gram-negative, aerobic, non-motile rods that are $1.5-2.0 \mu \mathrm{m}$ long and $0.6-0.8 \mu \mathrm{m}$ wide. Growth is detected at $5-30{ }^{\circ} \mathrm{C}$ with an optimum at $25^{\circ} \mathrm{C}$. pH range for growth is $6-11$ with an optimum at $\mathrm{pH} 7$. Growth occurs at $3-10 \% \mathrm{NaCl}$ with an optimum at $3 \%$. Oxidase- and catalase-positive. Alginic acid, tyrosine and aesculin are degraded, but agar, casein, cellulose, chitin, inulin, carboxymethylcellulose, Tween 80, DNA and yeast cells are not. $\mathrm{H}_{2} \mathrm{~S}$ and indole are not produced. Starch is not hydrolysed. Nitrate is reduced to nitrite and gas. Ammonium sulfate and urea are not used as sole nitrogen sources for growth. Negative for utilization of L-arabinose, adonitol, fructose, rhamnose, sorbitol, xylitol, D-fucose, D-arabitol and Larabitol, positive for arbutin and weakly positive for mannitol and gluconate as sole carbon sources with the API 50CH system. Major fatty acids are $\mathrm{C}_{16: 0}, \mathrm{C}_{18: 1} \omega 7 \mathrm{c}$ and 11-methyl $\mathrm{C}_{18: 1} \omega 7 c . \mathrm{C}_{10: 0}, \mathrm{C}_{12: 0}, \mathrm{C}_{18: 0}, \mathrm{C}_{12: 0} 3-\mathrm{OH}$ and $\mathrm{C}_{16: 0} 2-\mathrm{OH}$ are present as minor components. Major ubiquinone is Q-10. DNA G $+\mathrm{C}$ content of the type strain is $55-59.4 \mathrm{~mol} \%$.

The type strain is NBRC $15792^{\mathrm{T}}\left(=\mathrm{ATCC} 700000^{\mathrm{T}}=\mathrm{CIP}\right.$ $105975^{\mathrm{T}}=$ DSM $5823^{\mathrm{T}}=$ IAM $\left.14463^{\mathrm{T}}\right)$.

\section{Acknowledgements}

We thank Dr K. Isono (NBRC) for valuable comments on an earlier version of the manuscript.

\section{References}

Arahal, D. R., Macián, M. C., Garay, E. \& Pujalte, M. J. (2005). Thalassobius mediterraneus gen. nov., sp. nov., and reclassification of Ruegeria gelatinovorans as Thalassobius gelatinovorus comb. nov. Int J Syst Evol Microbiol 55, 2371-2376.

Brosius, J., Palmer, M. L., Kennedy, P. J. \& Noller, H. F. (1978). Complete nucleotide sequence of a $16 \mathrm{~S}$ ribosomal RNA gene from Escherichia coli. Proc Natl Acad Sci U S A 75, 4801-4805.

Bruhn, J. B., Nielsen, K. F., Hjelm, M., Hansen, M., Bresciani, J., Schulz, S. \& Gram, L. (2005). Ecology, inhibitory activity and morphogenesis of a marine antagonistic bacterium belonging to the Roseobacter clade. Appl Environ Microbiol 71, 7263-7270.

Ezaki, T., Hashimoto, Y. \& Yabuuchi, E. (1989). Fluorometric deoxyribonucleic acid-deoxyribonucleic acid hybridization in microdilution wells as an alternative to membrane filter hybridization in which radioisotopes are used to determine genetic relatedness among bacterial strains. Int J Syst Bacteriol 39, 224-229.

Felsenstein, J. (1985). Confidence limits on phylogenies: an approach using the bootstrap. Evolution 39, 783-791.

González, J. M., Covert, J. S., Whitman, W. B., Henriksen, J. R., Mayer, F., Scharf, B., Schmitt, R., Buchan, A., Fuhrman, J. A. \& other authors (2003). Silicibacter pomeroyi sp. nov. and Roseovarius nubinhibens sp. nov., dimethylsulfoniopropionate-demethylating bacteria from marine environments. Int J Syst Evol Microbiol 53, 1261-1269.

Gutell, R. R., Larsen, N. \& Woese, C. R. (1994). Lessons from an evolving rRNA; $16 \mathrm{~S}$ and $23 \mathrm{~S}$ rRNA structures from a comparative perspective. Microbiol Rev 58, 10-26.

Izumida, H., Adachi, K., Nishijima, M., Endo, M. \& Miki, W. (1995). Akalone: a novel xanthine oxidase inhibitor produced by the marine bacterium, Agrobacterium aurantiacum sp. nov. J Mar Biotechnol 2, 115-118.

Kimura, M. (1980). A simple method for estimating evolutionary rates of base substitutions through comparative studies of nucleotide sequences. J Mol Evol 16, 111-120.

Labrenz, M., Collins, M. D., Lawson, P. A., Tindall, B. J., Schumann, P. \& Hirsch, P. (1999). Roseovarius tolerans gen. nov., sp. nov., a budding bacterium with variable bacteriochlorophyll $a$ production from hypersaline Ekho Lake. Int J Syst Bacteriol 49, 137-147.

Lau, K. W. K., Ng, C. Y. M., Ren, J., Lau, S. C. L., Qian, P. Y., Wong, P. K., Lau, T. C. \& Wu, M. (2005). Owenweeksia hongkongensis gen. nov., sp. nov., a novel marine bacterium of the phylum 'Bacteroidetes'. Int J Syst Evol Microbiol 55, 1051-1057.

Martens, T., Heidorn, T., Pukall, R., Simon, M., Tindall, B. J. \& Brinkhoff, T. (2006). Reclassification of Roseobacter gallaeciensis Ruiz-Ponte et al. 1998 as Phaeobacter gallaeciensis gen. nov., comb. nov., description of Phaeobacter inhibens sp. nov., reclassification of Ruegeria algicola (Lafay et al. 1995) Uchino et al. 1999 as Marinovum algicola gen. nov., comb. nov., and emended descriptions of the genera Roseobacter, Ruegeria and Leisingera. Int J Syst Evol Microbiol 56, 1293-1304

Mesbah, M., Premachandran, U. \& Whitman, W. B. (1989). Precise measurement of the $\mathrm{G}+\mathrm{C}$ content of deoxyribonucleic acid by highperformance liquid chromatography. Int J Syst Bacteriol 39, 159-167.

Nakagawa, Y. \& Yamasato, K. (1993). Phylogenetic diversity of the genus Cytophaga revealed by $16 \mathrm{~S}$ rRNA sequencing and menaquinone analysis. J Gen Microbiol 139, 1155-1161.

Nakagawa, Y., Sakane, T., Suzuki, M. \& Hatano, K. (2002). Phylogenetic structure of the genera Flexibacter, Flexithrix, and Microscilla deduced from 16S rRNA sequence analysis. J Gen Appl Microbiol 48, 155-165.

Petursdottir, S. K. \& Kristjansson, J. K. (1997). Silicibacter lacuscaerulensis gen. nov., sp. nov., a mesophilic moderately halophilic bacterium characteristic of the Blue Lagoon geothermal lake in Iceland. Extremophiles 1, 94-99.

Rüger, H. J. \& Höfle, M. G. (1992). Marine star-shaped-aggregateforming bacteria: Agrobacterium atlanticum sp. nov.; Agrobacterium meteori sp. nov.; Agrobacterium ferrugineum sp. nov., nom. rev.; Agrobacterium gelatinovorum sp. nov., nom. rev.; and Agrobacterium stellulatum sp. nov., nom. rev. Int J Syst Bacteriol 42, 133-143.

Rustigian, R. \& Stuart, C. A. (1941). Decomposition of urea by Proteus. Proc Soc Exp Biol Med 47, 108-112. 
Saitou, N. \& Nei, M. (1987). The neighbor-joining method: a new method for reconstructing phylogenetic trees. Mol Biol Evol 4 406-425.

Schaefer, J. K., Goodwin, K. D., McDonald, I. R., Murrell, J. C. \& Oremland, R. S. (2002). Leisingera methylohalidivorans gen. nov., sp. nov., a marine methylotroph that grows on methyl bromide. Int J Syst Evol Microbiol 52, 851-859.

Smibert, R. M. \& Krieg, N. R. (1981). General characterization. In Manual of Methods for General Bacteriology, pp. 409-443. Edited by P. Gerhardt, R. G. E. Murray, R. N. Costilow, E. W. Nester, W. A. Wood, N. R. Krieg \& G. B. Phillips. Washington, DC: American Society for Microbiology.

Suzuki, M., Nakagawa, Y., Harayama, S. \& Yamamoto, S. (2001). Phylogenetic analysis and taxonomic study of marine Cytophaga-like bacteria: proposal for Tenacibaculum gen. nov. with Tenacibaculum maritimum comb. nov. and Tenacibaculum ovolyticum comb. nov., and description of Tenacibaculum mesophilum sp. nov. and Tenacibaculum amylolyticum sp. nov. Int J Syst Evol Microbiol 51, 1639-1652.
Swofford, D. L. (2002). PAUP ${ }^{*}$ : Phylogenetic analysis using parsimony ( ${ }^{\star}$ and other methods), version 4. Sunderland, MA: Sinauer Associates.

Thompson, J. D., Gibson, T. J., Plewniak, F., Jeanmougin, F. \& Higgins, D. G. (1997). The CLUSTAL_X windows interface: flexible strategies for multiple sequence alignment aided by quality analysis tools. Nucleic Acids Res 25, 4876-4882.

Uchino, Y., Hirata, A., Yokota, A. \& Sugiyama, J. (1998). Reclassification of marine Agrobacterium species: proposals of Stappia stellulata gen. nov., comb. nov., Stappia aggregata sp. nov., nom. rev., Ruegeria atlantica gen. nov., comb. nov., Ruegeria gelatinovora comb. nov., Ruegeria algicola comb. nov., and Ahrensia kieliense gen. nov., sp. nov., nom. rev. J Gen Appl Microbiol 44, 201-210.

Wayne, L. G., Brenner, D. J., Colwell, R. R., Grimont, P. A. D., Kandler, O., Krichevsky, M. I., Moore, L. H., Moore, W. E. C., Murray, R. G. E. \& other authors (1987). International Committee on Systematic Bacteriology. Report of the ad hoc committee on reconciliation of approaches to bacterial systematics. Int J Syst Bacteriol 37, 463-464.

Whitman, W. B. (2006). Error in G $+\mathrm{C}$ calculations. Int J Syst Evol Microbiol 56, 1177. 